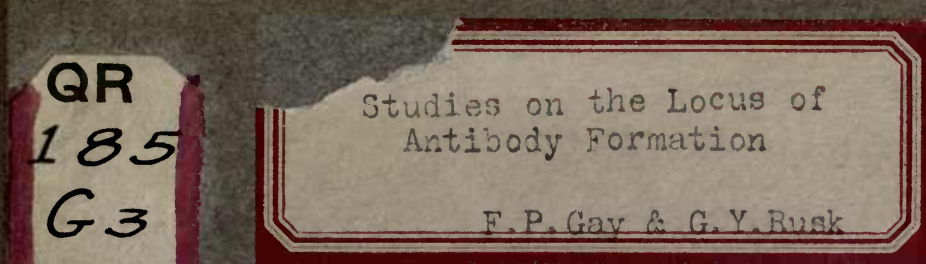

1913

UC-NRLF

||||||||||||||||||||||||||||||||||

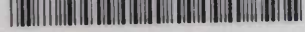

\$B 96 96?

$\underbrace{\infty}_{\infty}$

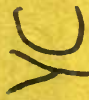




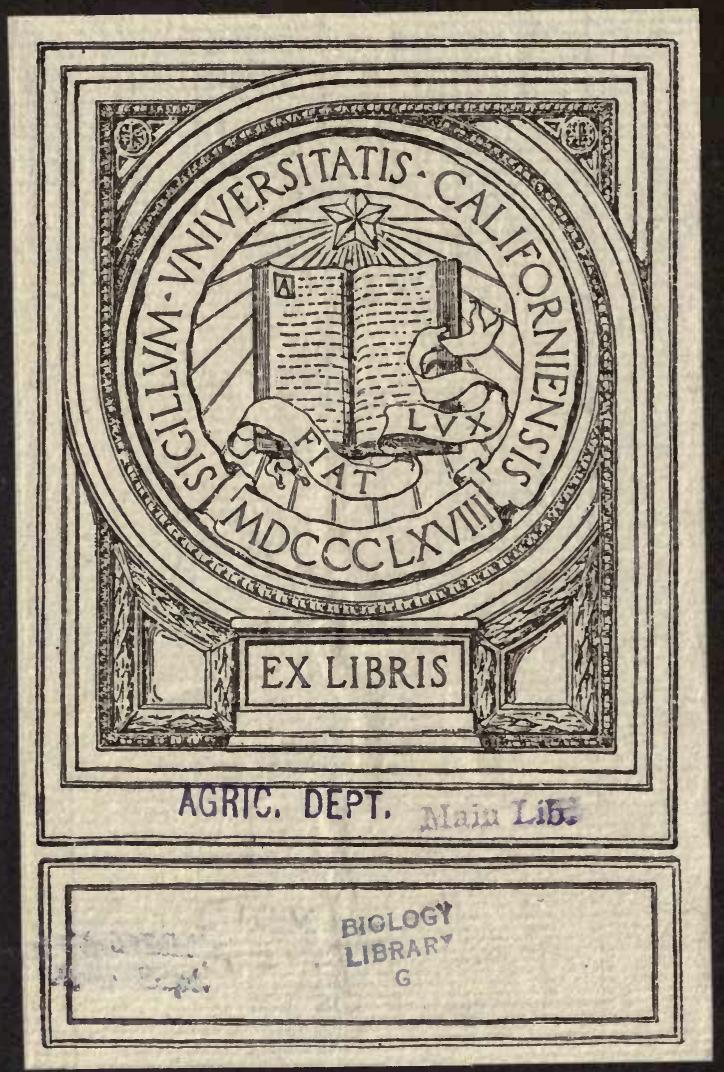




\title{
STUDIES ON THE LOCUS OF ANTIBODY FORMATION
}

BY

\author{
FREDERICK P. GAY AND G. Y. RUSK
}

From the Hearst Laboratory of Pathology and Bacteriology

University of California

Reprinted from the Transactions of the Fifteenth International

Congress on Hygiene and Demography, held at

Washington, D. C., September 23-28, 1912

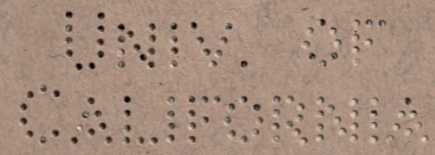





\section{STUDIES ON THE LOCUS OF ANTIBODY FORMATION.}

Frederick P. GAY and G. Y. Rusk, from the Hearst Laboratory of Pathology and Bacteriology, University of California.

Since the critical work of Knorr ${ }^{1}$ on toxins it has been generally accepted that antibodies are formed, not by a simple inversion of antigens, but by a reaction on the part of the cells of the animal that has received the antigen. Correlatively, it has been assumed that certain cells have a particular affinity for a given antigenic substance and are presumably specifically fitted to produce the corresponding antibody. Ehrlich's receptor hypothesis, while stating this assumption more concretely, has in no instance given direct proof that any particular type of cell gives rise to any given antibody. The experiment of Wassermann and Takaki ${ }^{2}$ that demonstrated the apparent neutralization of tetanus toxin by brain substance is no longer regarded as a proof of the nerve-cell origin of tetanus antitoxin. Indeed the work of Loewi and Meyer ${ }^{3}$. would show that injection of the toxin into nervous tissue produces an increased susceptibility of the animal to tetanus toxin rather than an increased resistance. The fact that tetanus toxin disappears rapidly from the circulating blood of susceptible animals and may soon be demonstrated in the central nervous system would not, it would seem, prove conclusively that the toxin may not also have been fixed and neutralized by other body cells. At least it would seem necessary to assume that the cells responsible for the antitoxin formation must first fix the antigen. This proof of antigen fixation, indeed, constitutes one of the methods that have been employed in searching for the locus of antibody formation. The only other apparent method of determining antibody origin would seem to lie in the early demonstration of antibodies in given cell groups before they are demonstrable in the circulating blood.

Very little information, therefore, on the site of antibody formation has been gained from studies on toxin and antitoxin. Our information, inconclusive as it is, has been obtained from the work with other antibodies, and we would do well to consider first what data have been accumulated in respect to each of the antibody types in turn. 


\section{RATTERIOLYSINS.}

Pfeiffer and Marx ${ }^{4}$ inaugurated the first systematic attempts to discover the origin of lytic antibodies. Their work would seem to indicate very clearly that the protective antibodies directed against the cholera spirillum are elaborated in the leucopoietic organs, particularly in the spleen, but to a less extent in the bone marrow, inasmuch as extracts of these organs protect guinea pigs from infection before the blood serum does. Deutsch ${ }^{5}$ essentially corroborated these findings with $B$. typhosus and Castellani ${ }^{6}$ with $B$. dysenteriae. Levaditi's ${ }^{7}$ conclusions from his work with the spirillum of hen septicemia were likewise corroborative, but his conclusions would not seem justified by the experimental evidence. These authors all agree that the spleen is not essential, as its removal at best but slightly inhibits antibody formation; the bone marrow and lymph nodes are secondarily concerned.

A careful inspection of Levaditi's experiments would seem to point to the blood stream as a possible source of antibodies, although his conclusions are different. Several authors, however, have attempted to disprove experimentally the local or leucocytic origin of the bacteriolysins. Thus Stenstrom ${ }^{8}$ found that the injection of bacteria plus leucocytes led to less antibody production than the injection of bacteria alone. Pfeiffer and Marx found less antibodies in the ground leucocytes of immunized animals than in the plasma. Deutsch found the lysins were not present in peritoneal exudate and Paetsch ${ }^{\circ}$ extended this finding so as to include both pleural and peritoneal exudates and the lining endothelia of these cavities.

Violle's ${ }^{10}$ injections into the gall bladder for the rapid production of antibodies indicate the possible function of the liver in this connection, which is emphasized more distinctly in work with other antibodies.

\section{HEMOLYSINS.}

Metchnikoff ${ }^{11}$ and Cantacuzène ${ }^{12}$ originally suggested, on what would seem to be largely philosophical grounds, that the hemolysins may be formed by the leucocytes owing to the recognized phagocytosis of blood cells by the mononuclears. The output of "fixatives," according to Metchnikoff, varies directly with the degree of phagocytosis. There is direct evidence that goes to prove, however, that these bodies are not formed in the blood stream. McGowan ${ }^{13}$ showed that no leucocytosis follows the injection of alien blood and Hektoen and Carlson ${ }^{14}$ have shown by transfusion experiments that the antigenic properties of foreign blood cells disappear from the circulation within seven hours. 
Among the fixed tissues, the liver and spleen seem to have shared the honors as the possible sites of hemolysin formation. Leuckhardt and Becht, ${ }^{13}$ following the work of Hektoen and Carlson, found that the spleen alone of the organs in a dog that has received goat or rat corpuscles 24 hours previously has the property of immunizing new animals. As a proof of the temporary location of the red blood cells that have been injected, this evidence is undoubted, although well recognized from other work; as a proof of the spleen as the site of antibody formation it would seem to be negative. The statement by London ${ }^{16}$ that splenectomy decreases the formation of hemolysins is categorically denied by Jakuschewitch. ${ }^{17}$ Brezina ${ }^{18}$ found that a specific serum against the leucopoietic organs had no effect in disturbing hemolysin formation. Carrel and Ingebristen ${ }^{19}$ have produced hemolysins in the growing embryonic spleen.

The evidence in favor of the liver as the site of hemolysin formation is more positive. Both Cantacuzène ${ }^{12}$ and McGowan ${ }^{13}$ have shown the function of Küpfers cells in the destruction of red blood corpuscles. Muller, ${ }^{20}$ in an interesting paper, has apparently traced normal hemolysin formation to the liver and has even been able to stimulate its excretion in the liver suspended in Ringer's solution outside the body, by transfusing it with solutions containing iodine (iodipin). A further contribution to the stimulating effect of iodin compounds is given by Hektoen ${ }^{21}$ who was able to increase the output of hemolytic sensitizers in dogs by injecting sodium iodoxybenzoate. Viollés ${ }^{10}$ method of producing antibodies by gall-bladder injection has already been referred to under bacteriolysins.

\section{AGGLUTININS.}

Whereas the evidence for bacteriolysin formation seemed to favor formation in the spleen or liver, the evidence for the locus of origin of the bacterial agglutinins points distinctly to the blood stream. Thus the work of Deutsch, ${ }^{5}$ Castellani, ${ }^{6}$ Rath, ${ }^{22}$ Weil and Braun, ${ }^{23}$ and Kraus and Schiffmann ${ }^{24}$ all shows that the agglutinins appear in the blood serum before they are present in the extract of any organ. Although Gruber ${ }^{25}$ originally suggested that the polymorphonuclears form the agglutinins, no experimental evidence goes to prove this. The experiments of Achard and Bensaud, ${ }^{26} \mathrm{Widal}$ and Sicard, ${ }^{27}$ of Paetsch, ${ }^{9}$ and of Kraus and Schiffmann ${ }^{24}$ all seem to disprove leucocytic or local origin.

There is some evidence of agglutinin formation in the spleen offered by v. Emden, ${ }^{28} \mathrm{Jatta}^{, 29}$ and Girgoleff. ${ }^{80}$

PRECIPITINS (ANTIBODIES OF SOLUBLE ANTIGENS).

In the case of precipitin formation, again the evidence seems divided. It is shown by two sets of observers (Petit and Carlson, ${ }^{81}$ 
Vaughan, Cumming, and McGlumphy ${ }^{32}$ ) that soluble antigenic substances like egg white or serum apparently disappear within a few hours from the circulating blood. This is shown by the impossibility of producing, in the one set of experiments, antibodies in another animal that is liberally transfused with such blood, and, on the other hand, by the failure to produce anaphylaxis in guinea pigs to the substance originally injected (egg white, Vaughan and collaborators). In apparent contradiction are the observations of several observers on the relation of leucocytosis to precipitin formation. Thus both Cantacuzène ${ }^{33}$ and Swerew ${ }^{34}$ have noted a marked hyperleucocytosis preceded by an absolute decrease in polymorphonuclears, which may reasonably be related to the liberation of precipitins. This observation fits in neatly with that of Hiss and Zinsser, ${ }^{35}$ who obtained nonspecific bacterial precipitins from leucocytic extracts, and that of Stenstrom, ${ }^{8}$ who found that hemologous leucocytes injected with the precipitinogen increases precipitin output. Kraus and Schiffmann ${ }^{24}$ emphatically regard the blood as the source of precipitins, whereas Cantacuzène, in spite of his evidence in favor of the leucocytes, is inclined to trace precipitin formation to the spleen.

The liver is by no means to be overlooked in discussing precipitin formation. The work of Manwaring, ${ }^{36}$ of Nolf, ${ }^{37}$ and of Balizot, ${ }^{38}$ on anaphylactic shock, would seem to point to the liver as the seat of action, and so, indirectly, owing to the relation that exists between anaphylaxis and precipitins, as a possible location of the latter substances.

It is evident from this brief survey of the literature that no general statement can be made on the locus of antibody formation in general. It may well be that each of the antibody types is produced in a different place or places. But even when we consider the possible seat of origin of any particular class of antibodies, we are struck by the apparent confusion in the acquired data. In the case of any of them we may still say that the antibody may be formed either in the blood stream or in the fixed tissues. There seems greatest agreement on the point that antibodies are formed either by the leucocytes or the leucocyte-forming organs. And yet a good deal of recent work points with increasing emphasis to the liver, an organ which, in view of its other functions, might logically likewise serve to produce antibodies.

Our own studies on antibody formation have been actively in progress for over a year. We regard them hitherto as largely preliminary and they have led rather toward establishing certain methods of attack and the evolution of working hypotheses of possible heuristic value than to any conclusion on the main subject at issue. 
Certain by-products of the investigation are in themselves of distinct interest, although their results are negative in so far as explaining antibody formation is concerned. Two incidental investigations may first be summarized before dealing with the work that bears more directly on the site of antibody formation:

\section{THE EFFECT OF IODIPIN ON THE OUTPUT OF ARTIFICIAL HEMOLYSINS. ${ }^{30}$}

Muller's ${ }^{20}$ experiments led him to the conclusion that both normal sensitizer (amboceptor) and alexin are formed in the liver, but that their output depends on the stimulating action of the iodin of the thyroid gland. This author finds that the injection of thyroid preparations, or of various iodine preparations, notably of iodipin (Merck, 25 or 10 per cent of iodin), produces a distinct increase in from 24 to 36 hours of the normal hemolysins in rabbits and other animals. As already stated, this increase comprises not only an increase in alexin, as tested on blood cells sensitized by an artificial hemolysin, but an increase of the normal hemolytic sensitizer. Hektoen ${ }^{21}$ has further found an increase in hemolytic sensitizers in dogs that received a single dose of goat's blood over the amount produced in control dogs on giving injections of sodium iodoxybenzoate. This alleged increase of normal hemolytic sensitizers immediately suggested the importance of determining the effect of iodin on artificial hemolysins, not only as a matter in itself of theoretical and perhaps of practical importance, but as bearing on the origin of antibody formation. Differences that might appear - in the hemolytic potency of the sera of immunized animals would presumably be more striking than corresponding differences in normal hemolysins, owing to the much greater strength of immune sera.

Our experiments deal, first, with the effect of a single injection of iodipin (Merck, 10 per cent) in rabbits that had been immunized by several injections of washed guinea-pig corpuscles. In several experiments a control animal that had been immunized in a similar manner, but that received no iodipin, was carried through. The animals with and without iodipin were bled before injection from the ear and at intervals subsequently; the separate sera were heated at once to $56^{\circ}$ for one-half hour, and at the end of the experiment all were tested for hemolytic units at the same time with the same corpuscles and alexin. In other experiments a critical intravenous reinjection of the antigenic blood was given in two highly immunized rabbits, and on the following day one of them was given iodipin. Both sera were then tested at intervals for hemolytic potency. There was no evidence from any of these experiments that the injection of iodipin will increase the output of artificial hemolysins in the immunized rabbits. 
II. HISTOLOGICAL STUDIES OF THE TISSUES IN IMMUNIZED ANIMAIS WITH A COMPARISON OF CHEMICAL AND MICROCHEMICAL TESTS FOR GLYCOGEN. 40

The histopathological studies of Gay and Southard ${ }^{41}$ in serum anaphylaxis in the guinea pig have seemed an interesting contribution to the relation of structure to function. These authors found that anaphylactic intoxication is accompanied by definite lesions in the nature of hemorrhages and more particularly by fatty changes in parenchyma and in the endothelium. These endothelial fat changes could be produced in a few minutes following intravenous injection and obviously bear direct relation to the cyclonic symptoms of the syndrome. It occurred to us that similar evidence of functional cellular activity might be histologically demonstrable in the cells that are engaged in antibody formation. For this purpose rabbits were highly immunized by repeated intravenous injection of washed guinea-pig corpuscles and following a rest of two or more weeks were given a critical reinjection of 1 cubic centimeter of washed guinea-pig blood and at subsequent intervals bled and the tissues fixed in various ways and stained by many methods. The critical reinjection was aimed, obviously, to obtain the antibodyproducing cells in a condition of highest activity.

In the first experiment a series of immunized rabbits received each the critical reinjection of antigen and were then bled at 1,4 , and 24 hours and 4 and 6 days subsequently. A careful histological study of tissues from this series showed in the 24-hour animal a very marked increase of glycogen in the liver (Best's carmine stain, alcohol fixation). The animals bled before and after this period gave a regular increase and decrease of glycogen to the 24-hour maximum. A more careful control of this experiment has involved us in technical difficulties that seemed too time consuming and led, moreover, to far less encouraging results than the first experiment. The question of the effect of starvation on the amount of glycogen alone seemed unsurmountable; it was found, for example, that rabbits that have not been fed for two days have stomachs stuffed with food. We are still in doubt as to the significance of our first find of increased glycogen. An attempt to correlate the microchemical reaction of glycogen with a careful chemical analysis of total glycogen in the liver has, however, led to results of importance. So far as we are aware, there has been no systematic comparison between the chemical analysis of an organ and microchemical staining reactions in a sample of it. Dr. Rusk has studied the amount and distribution of glycogen in sections of 22 rabbit livers stained by the Ehrlich iodin method and the Best carmine method, with a chemical analysis of a greater (weighed) portion of the same livers, following Pflüger's 
method to the conversion of glycogen to glucose, and at this point introducing Betrand's modification of Fehling's method as more accurate in measuring the amount of copper reduced. It is found that the microchemical method serves to give somewhat definite information as to the amount of glycogen present, but within a limited range only, for when the chemical analysis showed very much or very little glycogen the staining method was at times wholly inadequate.

III. THE FATE OF HORSE SERUM INJECTED INTRAVENOUSLY IN NORMAL AND IMMUNIZED RABBITS.

The two general methods that have been and may be employed in seeking antibody origin are either to trace the course of the injected antigen to some group of cells or to seek the precocious appearance of antibodies in extracts of a given group of cells. The latter method is the one that has been used most frequently, but it is the former that we have employed. Our observations, some of which have already been published, ${ }^{42}$ began with a study of the fate of horse serum injected into the blood stream of rabbits that had been immunized against horse serum. They have since led to further studies on the result of an initial injection of horse serum in normal rabbits. In all instances our results deal with an injection of one cubic centimeter of serum intravenously.

In beginning the experiments with immunized animals it was necessary first to determine the best method of detecting the antigen that was reinjected. It was found that when horse serum is injected intrarenously in rabbits that have a high precipitin content for horse serum it nevertheless remains demonstrable by the fixation reaction or the precipitin reaction for 24 hours. The reactions are carried out by adding the antigen-containing antiserum to a pure antiserum. After 48 hours the antigen is no longer demonstrable. The persistence of the antigen in the immune animal is accompanied by a fall in the precipitin value of serum (negative phase). It is of interest to note that although this antigen-containing antiserum will not precipitate or fix alexin spontaneously, it will react with another antigenic antiserum as well as with a pure antiserum. It was rather surprising to us to fail in any conclusive demonstration of the antigen by the fixation reaction in extracts of the organs of these same immunized animals (spleen, lymph nodes, liver, kidney, and muscles) either at the same time the antigen is present in the blood or even 24 hours later.

Of undoubtedly greater significance is the fact that neither the antigen-containing antiserum, nor the organ extracts of the same animal will sensitize guinea pigs to subsequent intoxication by horse 
serum. We compared the fixing values of pure horse serum and antigenic antiserum, and although one fixing dose of the horse serum will sensitize guinea pigs, many fixing doses of the antigenic antiserum fail to do so (at least 100). This would explain the results of Vaughan, Cumming, and McGlumphy ${ }^{82}$ who found that egg white apparently disappears from the circulation in a few hours when tested for by the anaphylaxis reaction. It is perhaps also in harmony with the work of Hektoen and Carlson ${ }^{14}$ and of Petit and Carlson ${ }^{31}$ who proved by transfusion that the antibody-inciting factor in blood cells or in serum leaves the circulation in a few hours. We might possibly assume that the factor in the antigen that produces the antibody differs from the one that unites with it. (Cfr. Bang and Forsmann. ${ }^{43}$

The results of injecting horse serum into normal animals are also of interest. 'The horse serum is detectable by the precipitin and fixation reactions for several days. It apparently does not sensitize in large doses even after 24 hours. The fixation and precipitinogen antigen is present not only in the blood, but also in the various organ extracts (in this case carefully freed of blood) in uniform amounts on the seventh, eighth, ninth, and tenth day. Of greatest importance is the fact that the corresponding antibodies have begun to appear in the serum two or three days before the antigen disappears. Similar facts have been noted by Hintze. ${ }^{44}$ It is evident then that not all the antigen is used up in producing the antibody. We have to imagine either that the antigen continues to unite with the cell or stimulate the cell for some time after antibodies appear, or that the antibody stimulant differs from the antigen fraction that unites with the antibody. This latter hypothesis seems to us for the present the most valuable for a working basis. It explains, moreover, our own failure to produce anaphylaxis (cfr. also Vaughan and his collaborators), and also the results of Hektoen and Carlson. We are continuing our work with this as a working hypothesis and also with a possible further elucidation of the obscure phenomenon of anaphylaxis in mind.

${ }^{1}$ Knorr: Fortschr. der Mediz., etc., rol. 15 (1897), p. 657.

${ }^{2}$ Wassermann and Takakl : Berlin. Klin. Wochen., vol. 35 (189S), p. 5.

'Loewi and Meyer: Archiv fül experiment. Path., vol. 59 (1908), p. 355.

' Pfeiffer and Marx: Zeit für Hygiene, vol. 27 (1898), p. 272.

- Deutsch : Annales de l'Inst. Pasteur, vol. 13 (1899), p. 689.

- Castellani: Zeit. für Hygiene, vol. 37 (1901), p. 381.

${ }^{\top}$ Leraditi: Annales de l'Iust. Pasteur. vol. 18 (1904), p. 511.

- Stenstrom : Zeit. fïr Immunitïitsforsch., vol. 8 (1911), p. 483.

- Paetsch: Centralblatt für Bakt., Orig. I, vol. 60 (1911), p. 255.

${ }^{10}$ Viollé : Annales de l'Inst. I'asteur, vol. 26 (1912), pp. 381, 467.

"Metchnikoff : I'immunité dans les maladies infectieuses, p. 103; Annales de l'Inst. Pasteur, vol. 13 (1899), p. 737.

${ }^{10}$ Cantacuzène: Annales de l'Inst. Pasteur, vol. 16 (1902), p. 522. 
${ }^{13}$ MeGowan: Journal of Pathology and Bacteriology, vol. 14 (1909), 379 ; vol. 15 (1911), 262.

${ }^{14}$ Hektoen and Carlson: Transact. Chicago Path. Soc., vol. S (1909), p. 4; Journ. of Infect. Diseases, vol. 7 (1910), p. 319.

${ }^{15}$ Lenckhardt and Becht: Transact. Chicago Path. Soc., vol. 8 (1911), p. 202.

${ }^{16}$ London: Archiv für biologische Wissenschaften (1901), p. 328.

${ }^{17}$ Jakuschewitsch: Zeit. für Hygiene, vol. 47 (1904), p. 407.

${ }^{18}$ Brezina : Wein. Klin Wochenschr. (1905), p. 905.

${ }^{19}$ Carrel and Ingebristen: Journ A. M. A., vol. 58 (1911), p. 477.

${ }^{20}$ Muller : Central. für Bakt., I. Abt́,, Orig., vol. 57 (1911), p. 577.

${ }^{21}$ Heltoen: 'Transact. Chicago Path. Soc., vol. $\$$ (1911), p. 138.

${ }^{22}$ Rath: Central. für Bakt., vol. 25 (1899), 529.

${ }^{23}$ Weil and Braun: Biochem. Zeitschr., vol. 17 (1910), p. 337.

${ }^{24}$ Kraus and Schiffman: Annales de l'Inst. Pasteur, vol. 20 (1906), 225.

${ }^{25}$ Gruber: Münch. mediz. Wochenschr. (1897), Nos. 17 and 18.

${ }^{26}$ Achard and Bensand: Archiv für med. Experiment (1896), p. 748.

${ }^{27}$ Widul and Sicard: Annales de l'Inst. Pasteur, rol 11 (1897), p. 353.

${ }^{23}$ v. Emden : Zelt. für Hygiene, vol. 30 (1899), p. 19.

${ }^{20}$ Jatta : Zeit. für Hygiene, vol. 33 (1900), p. 185.

${ }^{30}$ Girgoleff : Zeit. für Immunitätsforsch, vol. 12 (1912), p. 401.

${ }^{81}$ Petit and Carlson: Jour. Infect. Diseases, vol. 10 (1912), p. 43.

${ }^{82}$ Vaughan. Cumming \& McGlumphy: Zeit. für Immunitätsforsch., vol. 9 (1911), p. 16.

${ }^{38}$ Cantacuzène: Annales de l'Inst. Pasteur, vol. 22 (1908), p. 54.

${ }^{34}$ Swerew : Rusaky Wratsch. (1910), p. 367 ; Ref. Jahresbericht der Immunitätsforschung, $\mathrm{VI}^{2}$, p. 527 .

${ }^{35}$ Hiss and Zinsser: Jour. Med. Research, vol. 19 (1908), p. 399.

${ }^{36}$ Manwaring: Zeitschr. für Immunitätsforsch., vol. 8 (1910), p. 1.

${ }^{87}$ Nolf: Archives internat. de Physiolog., Vol. X (1910), p. 37.

${ }^{38}$ Blaizot: Compt. rend. heb. Soc. de Biol., vol. 70 (1911), p. 383.

${ }^{30}$ Gay \& Rusk: Univ. Calif. Publ. Path., vol. 2, No. 7 (1912).

${ }^{40}$ Rusk: Univ. Calif. Publ. Path., vol. 2, No. 9 (1912).

41 Gay and Southard: Jour. Med. Research, vol. 16 (1907), p. 143.

${ }^{12}$ Gay and Rusk: Univ. Calif. Publ. Path., vol. 2, No. 6 (1912).

${ }^{43}$ Bang and Forssmann: Centralblatt für Bakt., I. Orig., XL (1905), p. 151.

* Hintze: Zeit. für Immunitätsforsch., vol. 6 (1910), p. 113.

\section{DISCUSSION.}

Dr. W. H. PARK: Observations made on the injection of toxins and antigens into the blood or into the subcutaneous or other tissues indicate that for many antibodies several varieties of cells take part. The blood in an animal highly immunized to diphtheria toxin contains about 100 times the quantity of antitoxin as the tissue fluids. If toxin is added to antitoxin, union slowly takes place and the combined toxin is no longer able to excite the production of antitoxin. When a horse having a strongly antitoxic blood is injected intravenously with a definite amount of toxin very little production of antitoxin takes place, because most of it is neutralized by the antitoxin in the blood. The same amount injected in scattered spots subcutaneously will produce a large amount of antitoxin. The part absorbed into the blood would meet the same fate as that injected intravenously. It 
seems, therefore, certain that some or all of the cells in the area in the subcutaneous tissues that the toxin reaches must take part in producing antitoxin. If toxin is injected through the trachea into the lungs it acts in the same way as when injected subcutaneously. I have seen similar, though not as definite, results with the injection of various bacterial antigens. These facts seem to suggest that more varied cells than Dr. Gay indicates may take part in antibody formation.

Dr. Vaugrn thinks that the ferment is formed by different cells according to the sensitizer used. He referred to the work of J. W. Vaughan on sensitization to cancer proteins in which it appears that the ferment is formed in the large mononuclear leucocytes and that the sensitization is transitory. The fact that the nonpoisonous part sensitizes may be due to the presence of a minute trace of unbroken proteins. However, this seems highly improbable because - this part does not sensitize to itself. 



कसTS FमनT IS DUE ON TTH

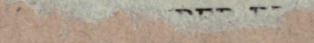




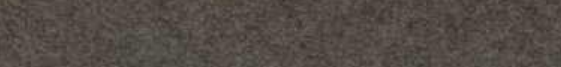

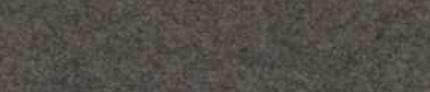

$$
\text { 3. }
$$

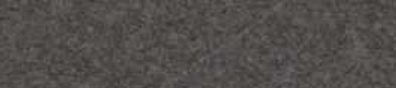

90 (3)

30 .

25.

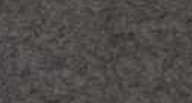

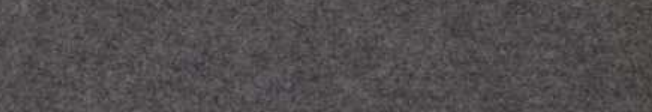

W.

6.

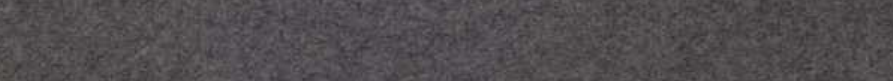

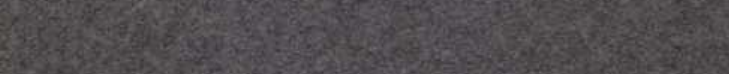

3.

1.2.

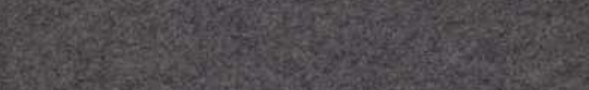

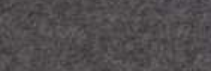

tist

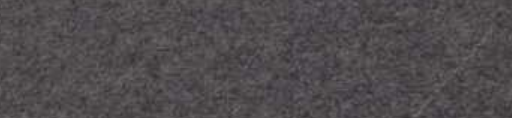

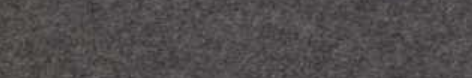

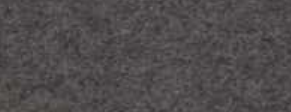

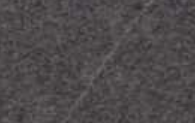

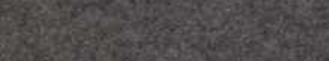

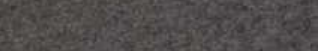

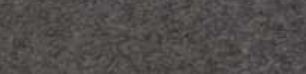

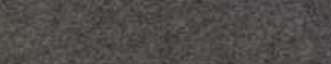

tong 